\title{
PELAKSANAAN ASURANSI KEBAKARAN PADA PT. ASURANSI TAKAFUL UMUM CABANG PADANG
}

\author{
Novalia Indra \\ Mahasiswa Pascasarjana (S2) STAIN Batusangkar \\ Program Studi Hukum Ekonomi Syariah, Jln. Jendral Sudirman, Batusangkar
}

\begin{abstract}
This qualitative descriptive research was purposed at describing the implementation of fire insurance in PT Insurance Takaful Umum Padang branch. The techniques of collecting data in this research were interview and study document. This research found that the implementation of fire insurance in PT insurance Takaful umum Padang branch was begun by filling the data in the application letter of fire insurance (SPPAK). Then PT insurance Takaful umum Padang branch produced the appointment in PSKI. The barrier of claim was happened because the consumer did not read and understand the appointment in PSKI.
\end{abstract}

Keywords: Implementation, Fire Insurance, PT Insurance Takaful Umum Padang Branch

\section{PENDAHULUAN}

Sehubungan dengan kebutuhan manusia yang semakin meningkat menimbulkan banyaknya tuntutan hidup yang harus dipenuhi. Hal inilah yang melatarbelakangi manusia sebagai makhluk yang dianugerahi akal dan pikiran oleh Tuhan Yang Maha Esa untuk mencari solusi atas semua kebutuhan hidupnya. Salah satu dari banyaknya kebutuhan manusia itu adalah kebutuhan terhadap rasa aman atas kedudukan atau keberadaan harta bendanya.

Setiap orang yang memiliki suatu benda tentu menghadapi risiko bahwa nilai dari benda itu akan berkurang, baik karena hilangnya benda itu maupun karena kerusakan atau karena musnah terbakar atau karena sebab lainnya (Prakoso dan Murtika, 2004:7). Hal ini yang menyebabkan seseorang selalu dalam kekhawatiran dan ketakutan terhadap terjadinya risiko.

Untuk mendapatkan rasa aman dan menghilangkan rasa kekhawatiran akan terjadinya risiko, maka dibutuhkan suatu lembaga penjamin (asuransi) yang dapat menjamin harta benda yang mereka miliki melalui pertanggungan yang dilakukan. Berhubungan dengan itu kebutuhan manusia akan asuransi merupakan suatu hal yang sangat pokok. Seseorang tidak akan tenang melaksanakan kegiatan sehari-harinya, apabila pikirannya dihantui 
oleh perasaan tentang pristiwa yang mungkin akan menimpa dirinya atau harta kekayaannya, di mana untuk mendapatkan barang itu membutuhkan biaya yang sangat besar dan mungkin saja sulit untuk mendapatkannya.

Selain biaya untuk membeli harta benda tersebut, kita juga harus memikirkan bagaimana kita harus menjaganya. Di sini timbul masalah baru lainnya, yaitu bagaimana agar setiap pemilik dari harta benda tersebut dapat terhindar dari kerugian yang lebih dikenal dengan istilah risiko, dan musibah yang tidak satu orang pun yang dapat memprediksi kapan akan terjadi. Misalnya terjadi peristiwa kebakaran menyebabkan orang kehilangan rumah dan harta bendanya, yang mana peristiwa kebakaran tersebut di luar kesalahannya.

Dalam hal ini diperlukan usaha antisipasi dalam menghadapi kemungkinan tersebut. Usaha antisipasi yang dapat dilakukan di sini adalah melalui suatu bentuk pertanggungan yang khusus menangani ganti rugi, yang mana saat sekarang lebih dikenal dengan istilah asuransi.

Adanya lembaga asuransi di dalam masyarakat adalah sebagai penaggulangan risiko yang mungkin akan terjadi baik terhadap harta maupun jiwa. Dengan cara memperalihkan risiko kepada pihak lain yang bersedia menerimanya dengan syaratsyarat tertentu (Salim, 2000: 8).

Untuk mengatasi kerugian yang terjadi akibat peristiwa kebakaran, maka masyarakat dapat mencari pihak-pihak (penanggung) yang sanggup menerima Risiko, yaitu dalam bentuk perjanjianperjanjian asuransi. Perjanjian asuransi dapat dilaksanakan asalkan adanya kesepakatan yang dibuat oleh para pihak, yaitu pihak tertanggung dan pihak penanggung. Tujuan perjanjian pertanggungan itu diadakan untuk mengalihkan risiko yang timbul dari peristiwa yang tidak diharapkan (mengalihkan risiko yang timbul dari pihak tertanggung kepada pihak penanggung).

Banyak para perorangan yang mengadakan pertanggungan-pertanggungan atas barang-barangnya ataupun badan jiwanya lebih menitikberatkan pengertian pertanggungan itu dari segi ekonomisnya. Tetapi apakah mereka mengerti akan apa arti pertanggungan itu dari segi hukumnya, kita juga tidak dapat memastikannya (Simanjutak, 1990: 1).

Dari sudut pandang orang yang ditanggung, asuransi adalah alat yang memungkinkannya menukar (substitute) biaya kecil tertentu (premi) dengan 
kerugian besar yang belum tentu di bawah suatu perjanjian. Di mana mereka (yang banyak) yang beruntung lolos dari kerugian akan membantu mereka (yang sedikit) yang tidak beruntung dengan mengganti kerugian yang mereka derita itu (Ali, 1993: 3).

Dari sudut pandang hukum, asuransi merupakan suatu kontrak (perjanjian) pertanggungan risiko antara tertanggung dengan penanggung. Penanggung berjanji akan membayar kerugian yang disebabkan risiko yang dipertanggungkan kepada tertanggung. Sedangkan tertanggung membayar premi secara periodik kepada penanggung. Jadi, tertanggung mempertukarkan kerugian besar yang mungkin terjadi dengan pembayaran tertentu yang relatif kecil (Darmawi, 2000: 2).

Jika dilihat dari pengertian asuransi syariah itu sendiri yang dikemukakan oleh Al- Fanjari mengartikan tadhamun, takaful, at- $t a^{\prime}$ min atau asuransi Syariah dengan pengertian saling menanggung atau tanggung jawab sosial. Sementara dalam fatwa MUI tentang pedoman asuransi Syariah memberikan definisi asuransi syariah (Ta'min, Takaful, Tadhamun) adalah usaha saling tolong menolong di antara sejumlah orang/pihak melalui investasi dalam bentuk asset dan atau dana tabarru' yang memberikan pola pengembalian untuk menghadapi risiko tertentu melalui akad (perikatan) yang sesuai dengan syariah (Sula, 2004: 32).

Suatu perjanjian yang telah dibuat dengan sah oleh kedua belah pihak, mempunyai kekuatan yang sama dengan Undang-Undang, sebagaimana mereka mentaati Undang-Undang demikian mereka juga harus melaksanakan dan mentaati perjanjian tersebut. Agar sahnya suatu perjanjian maka harus memenuhi beberapa persyaratan sebagaimana yang diatur dalam pasal 1320 KUH Perdata yang berbunyi "untuk sahnya perjanjian diperlukan 4 syarat antara lain 1) sepakat mereka yang mengikatkan diri;2) kecakapan untuk membuat suatu perikatan; 3) suatu hal tertentu; 4) suatu sebab yang halal".

Selain syarat-syarat yang ditentukan dalam pasal 1320 KUH Perdata di atas, dalam perjanjian asuransi juga diperlukan syarat khusus sebagaimana terdapat dalam pasal 251 KUHD yaitu tentang keharusan adanya pemberitahuan dari suatu keadaan yang diketahui tertanggung mengenai benda yang dipertanggungkan, sehingga penanggung dapat mengetahui jelas mengenai risiko yang akan ditanggungnya. Dengan demikian jelas bahwa adanya kewajiban bagi tertanggung untuk memberitahukan atau memberikan keterangan secara detail mengenai barang 
yang akan dialihkan risikonya, baik mengenai keadaan fisik, ancaman risiko dan sebagainya.

Asuransi kebakaran sebagai salah satu bentuk pertanggungan yang ada, bertujuan untuk memberikan perlindungan atau penjagaan terhadap harta kekayaan dari suatu risiko yang mungkin terjadi namun belum tentu kapan waktunya, pihak asuransi akan bertanggungjawab dengan memberikan ganti kerugian sesuai dengan perjanjian yang telah disepakati.

Berdasarkan hasil wawancara peneliti dengan staff karyawan PT. Asuransi Takaful Umum cabang Padang (Yusril Hasan 5 Mei 2014), bahwasanya pelaksanaan perjanjian dilaksanakan dengan cara meminta nasabah untuk membaca polis, setelah membaca semua isi polis nasabah menandatangani polis tersebut. Tetapi ketika nasabah diminta membaca polis, nasabah tersebut membaca atau tidak terhadap polis itu PT. Asuransi Takaful Umum cabang Padang tidak tahu. Sehingga dengan adanya tanda tangan dari pihak nasabah maka perjanjian antara pihak penanngung dan tertanggung sudah terjadi.

Dalam polis asuransi kebakaran takaful umum cabang Padang, polis asuransi kebakaran tersebut hanya sesuai dengan aturan undang-undang asuransi konvensional dan berdasarkan KUHD (Gunanto, 1984). Namun dalam praktiknya apakah pihak asuransi dalam hal ini Asuransi Kebakaran sudah betul-betul memenuhi tanggung jawabnya dalam menanggulangi risiko yang timbul, yaitu dengan memberikan ganti rugi kepada tertanggung secepatnya atau butuh waktu lama, dan apakah aturan-aturan syariah sudah dijalani dalam Asuransi kebakaran yang ada pada PT. Asuransi Takaful Umum cabang Padang. Hal inilah yang mendorong peneliti melakukan penelitian.

\section{METODE PENELITIAN}

Jenis penelitian ini bersifat kualitatif dengan metode deskriptif karena 1) dilaksanakan pada kondisi yang alamiah;2) lebih bersifat deskriptif, sumber data utama dalam penelitian kualitatif adalah kata-kata dan tindakan, sehingga tidak menekankan pada angka; 3) lebih menekankan pada proses daripada produk atau outcome; 4) analisis data dilakukan secara induktif; dan 5) lebih menekankan makna (data dibalik yang teramati) (Sugiyono, 2007: 9). Dalam mengumpulkan data yang dibutuhkan, peneliti menggunakan teknik pengumpulan data wawancara dan studi dokumen. Analisis data dilakukan melalui 3 tahap, yaitu data reduction (reduksi data); data display (penyajian data); dan Conclusion 
Drawing/Verification (Kesimpulan). Menurut Moleong, (2007: 307) aktivitas dalam analisis data kualitatif dilakukan secara interaktif dan berlangsung secara terus menerus pada setiap tahapan penelitian sehingga sampai tuntas, dan datanya sampai jenuh.

\section{HASIL PENELITIAN}

1. Pelaksanaan asuransi kebakaran pada PT. Asuransi Takaful Umum Cabang Padang di awali dengan pengisian data oleh calon tertanggung pada Surat Permohonan Penutupan Asuransi Kebakaran (SPPAK). Setelah dilakukan kata mufakat oleh kedua belah pihak untuk saling mengikatkan diri dalam asuransi kebakaran, maka berjalanlah pertanggungan objek yang dipertanggungkan. Kemudian, untuk lebih sahnya perjanjian maka PT. Asuransi Takaful Umum menerbitkan atau membuat polis atau Polis Standar Kebakaran Indonesia (PSKI) untuk si tertanggung yang disertai dengan kwitansi premi yang dibayarkan oleh pihak tertanggung ke penanggung. Risiko-risiko yang dijamin oleh pihak asuransi dalam asuransi kebakaran meliputi jaminan standar dan perluasan jaminan. Jaminan standar berupa kebakaran, petir, peledakan, kejatuhan pesawat terbang dan asap.

2. Pelaksanan pengajuan dan pembayaran klaim pada PT. Asuransi Takaful Umum Cabang Padang dimulai dengan pengisian formulir laporan klaim oleh tertanggung dan penyerahan polis beserta berita acara mengenai peristiwa kebakaran, berikut rincian tentang penyebab kerugian dan kerusakan. Apabila pihak tertanggung telah melengkapi semua persyaratan yang ditetapkan oleh pihak asuransi, maka pihak asuransi akan menindaklanjuti laporan klaim tersebut dengan melakukan penelitian dan pemeriksaan surat-surat dan dokumen terkait. Selanjutnya pihak asuransi akan menetapkan jumlah ganti kerugian sebanding dengan kerugian yang di derita oleh pihak tertanggung. Cepat atau lambatnya proses pembayaran ganti kerugian tersebut biasanya tergantung kepada prosedur yang diikuti oleh si tertanggung serta kelengkapan dokumen yang diperlukan oleh penanggung dalam permintaan ganti kerugian tersebut.

3. Dalam pelaksanaan asuransi kebakaran pada PT. Asuransi Takaful Umum Cabang Padang kendala yang dihadapi biasanya berasal dari peserta 
asuransi kebakaran itu sendiri. Pihak tertanggung sering tidak membaca dan memahami isi dari perjanjian yang terdapat dalam PSKI. Akibatnya pada saat pengajuan klaim banyak tertanggung yang tidak melengkapi persyaratan. Kurang lengkapnya data-data atau dokumen klaim oleh pihak tertanggung yang diajukan kepada penanggung mengakibatkan keterlambatan pembayaran ganti kerugian.

\section{PEMBAHASAN}

Perkembangan asuransi dalam sejarah Islam sudah lama terjadi. Istilah yang digunakan tentunya berbeda-beda, tetapi masing-masing memiliki kesamaan, yaitu adanya pertanggungan oleh sekelompok orang untuk menolong orang lain yang berada dalam kesulitan. Dalam Islam, praktik asuransi pernah dilakukan pada masa Nabi Yusuf as. Yaitu pada saat ia menafsirkan mimpi Raja Firaun. Tafsiran yang ia sampaikan adalah bahwa Mesir akan mengalami masa 7 (tujuh) panen yang melimpah dan diikuti dengan masa 7 (tujuh) tahun paceklik. Untuk menghadapi masa kesulitan (paceklik) itu, Nabi Yusuf as. Menyarankan agar menyisihkan sebagian dari hasil panen pada masa tujuh tahun pertama. Saran dari Nabi Yusuf as. Ini diikuti oleh Raja Firaun, sehingga masa paceklik bisa ditangani dengan baik (Wirdyaningsih, 2005: 179).

Pada masyarakat Arab sendiri terdapat sistem 'aqilah yang sudah menjadi kebiasaan mereka sejak masa pra-Islam. Aqilah merupakan cara penutupan (istilah yang digunakan oleh AM. Hasan Ali) dari keluarga pembunuh terhadap keluarga korban yang terbunuh. Ketika terdapat seseorang terbunuh oleh anggota suku lain, maka keluarga pembunuh harus membayar diyat dalam bentuk uang darah. Kebiasaan ini kemudian dilanjutkan oleh Nabi Muhammad SAW. Praktik 'aqilah yang dilakukan oleh masyarakat Arab ini sama dengan praktik asuransi pada saat ini, di mana sekelompok orang membantu untuk menanggung orang lain yang tertimpa musibah. Dalam hal kaitannya dengan praktik pertanggungan ini, Nabi Muhammad SAW. juga memuat ketentuan dalam pasal khusus pada Konstitusi Madinah, yaitu pasal 3 yang isinya "orang Quraisy yang melakukan perpindahan ke Madinah melakukan pertanggungan bersama akan saling bekerjasama membayar uang darah di antara mereka (Wirdyaningsih, 2005: 180).

Tidak dapat disangkal bahwa keberadaan asuransi syariah tidak dapat dilepaskan dari keberadaan asuransi 
konvensional yang telah ada sejak lama. Sebelum terwujudnya asuransi syariah, terdapat berbagai macam asuransi konvensional yang rata-rata dikendalikan oleh nonmuslim. Jika ditinjau dari segi hukum perserikatan Islam, asuransi konvensional hukumnya haram. Hal ini dikarenakan dalam operasional asuransi konvensional mengandung unsur gharar, maisir, dan riba. Pendapat ini disepakati oleh banyak ulama.

Di Malaysia, pernyataan bahwa asuransi konvensional hukumnya haram diumumkan pada tanggal 15 juni 1972 di mana Jawatan Kuasa Fatwa Malaysia mengeluarkan keputusan bahwa praktik asuransi jiwa di Malaysia hukumnya menurut Islam adalah haram. Selain itu Jawatan kuasa kecil Malaysia dalam kertas kerjanya yang berjudul "ke arah insurans secara Islami di Malaysia" menyatakan bahwa asuransi masa kini mengikuti cara pengelolaan Barat dan sebagian operasinya tidak sesuai dengan ajaran Islam.

Asuransi konvensional hukumnya haram, kemudian dipikirkan dan dirumuskan dalam bentuk asuransi yang bisa terhindar dari ketiga unsur yang diharamkan Islam. Berdasarkan hasil analisis asuransi yang termuat dalam substansi hukum Islam tersebut dapat menghindarkan prinsip operasional asuransi dari unsur gharar, maisir dan riba. Dengan adanya keyakinan umat Islam di dunia dan keuntungan yang diperoleh melalui konsep asuransi syariah lahirlah berbagai perusahaan asuransi yang mengendalikan asuransi berlandaskan syariah. Perusahaan yang mewujudkan asuransi syariah ini bukan saja perusahaan orang Islam, namun juga berbagai perusahaan bukan Islam ikut terjun ke dalam usaha asuransi syariah (Dewi, 2006: 138).

Tim Pembentukan Asuransi Takaful Indonesia (TEPATI) itulah yang kemudian menjadi perumus dan pendiri asuransi takaful Indonesia dengan mendirikan PT Asuransi Takaful Keluarga (Asuransi Jiwa) dan PT Asuransi Takaful Umum (Asuransi Kerugian). Pendirian dua perusahaan asuransi tersebut dimaksudkan untuk memenuhi Pasal 3 UU No. 2 Tahun 1992 tentang Usaha Perasuransian yang menyebutkan bahwa perusahaan asuransi jiwa dan perusahaan asuransi kerugian harus didirikan secara terpisah.

Langkah awal yang dilakukan TEPATI dalam membentuk asuransi takaful di Indonesia adalah melakukan studi banding ke Syarikat Takaful Malaysia pada tanggal 7 sampai dengan 10 September 1993. Hasil studi banding tersebut kemudian diseminarkan di Jakarta pada tanggal 19 
Oktober 1993 yang merekomendasikan untuk segera dibentuk Asuransi Takaful Indonesia. Langkah selanjutnya, TEPATI merumuskan dan menyusun konsep asuransi takaful serta mempersiapkan segala sesuatu yang dibutuhkan untuk mendirikan sebuah perusahaan asuransi.

Akhirnya pada tanggal 25 Agustus 1994 Asuransi Takaful Indonesia berdiri secara resmi. Pendirian ini dilakukan secara resmi di Puri Agung Room Hotel Syahid Jakarta. Izin operasional asuransi ini diperoleh dari Departemen Keuangan melalui Surat Keputusan Nomor: Kep-385/ KMK.017/1994 tertanggal 4 Agustus 1994 (Dewi, 2006: 141).

Saat ini perusahaan asuransi yang benar-benar secara penuh beroperasi sebagai perusahaan asuransi syariah ada tiga, yaitu Asuransi Takaful Keluarga, Asuransi Takaful Umum, Asuransi Mubarakah. Selain itu ada beberapa perusahaan asuransi konvensional yang membuka cabang syariah seperti MAA, Great Eastern, Tripakarta, Beringin life, Bumi Putra, Dharmala, dan Jasindo.

Dalam bahasa Arab Asuransi disebut at-ta'min, penanggung disebut $M u^{\prime} a m m i n$, sedangkan tertanggung disebut mu'amman lahu atau musta'min. at-ta'min memiliki arti memberi perlindungan, ketenangan, rasa aman, bebas dari rasa takut (Sula, 2004: 28), sebagaimana firman Allah dalam surat Quraisy ayat 4 yang berbunyi "Dialah Allah yang mengamankan mereka dari ketakutan" (Quraisy: 4).

Ayat di atas mendefInisikan istilah at-ta'min, "menta'minkan sesuatu, artinya adalah seseorang membayar atau menyerahkan uang cicilan untuk agar ia atau ahli warisnya mendapatkan sejumlah uang sebagaimana yang telah disepakati, atau untuk mendapatkan ganti terhadap hartanya yang hilang, dikatakan seseorang mempertanggungkan atau mengasuransikan hidupnya, rumahnya, dan mobilnya.

Al-Fanjari mengartikan tadhamun, takaful, at-ta'min atau asuransi syariah dengan pengertian saling menanggung atau tanggung jawab sosial. Ia juga membagi ta'min ke dalam tiga bagian, yaitu $t a^{\prime} m i n$ at-taawuniy, ta'min al tijari, dan ta'min al hukumiy (Sula, 2004: 29).

Menurut Mushtafa Ahmad Zarqa, makna asuransi secara istilah adalah kejadian. Adapun metodologi dan gambarannya dapat berbeda-beda, namun pada intinya, asuransi adalah cara atau metode untuk memelihara manusia dalam menghindari risiko (ancaman) bahaya yang beragam yang akan terjadi dalam 
hidupnya, dalam perjalanan kegiatan hidupnya atau dalam aktivitas ekonominya (Sula, 2004: 29).

Ruang lingkup asuransi kebakaran meliputi benda-benda bergerak dan benda-benda tidak bergerak. Termasuk di dalamnya benda-benda atau barang-barang bergerak adalah karena kebakaran itu tidak hanya terjadi pada benda- benda tetap saja melainkan juga terjadi pada benda-benda bergerak yang ditempatkan di dalam benda tidak bergerak. Dalam Pasal 295 ayat (1) dan ayat (2) KUHD disebutkan sebagai berikut. Ayat (1) dalam halnya pertanggungan atas barang-barang bergerak dan barang-barang dagangan yang disimpan dalam sebuah rumah, gudang, atau tempat penyimpanan maka apabila alat-alat pembuktian yang disebutkan dalam Pasal 273, 274, dan 275 KUHD tidak ada atau kurang sempurna, dapatlah hakim memerintahkan sumpah kepada si tertanggung. Ayat (2) kerugian harus dihitung menurut harga barang yang dipertanggungkan pada saat terjadinya kebakaran.

Maksud dari Pasal 295 ayat (1) KUHD menyatakan adanya perbedaan antara asuransi barang di mana hakim berwenang untuk menyuruh si terjamin bersumpah bahwa keterangannya benar. Kemudian maksud dari Pasal 295 ayat (2) KUHD adalah di mana kerugian yang diderita oleh terjamin adalah harga nilai barangbarang pada waktu terjadi kebakaran tetapi apabila barang-barang itu masih ada sisanya yang berharga, maka kerugian yang diderita itu adalah perbedaan antara harga barang-barang itu sebelum dan sesudah ada kebakaran.

Pasal 287 KUHD yang harus dimuat khusus dalam polis asuransi kebakaran oleh pembentuk Undang-Undang diberi arti penting kepada letak bangunan yang dijamin. Di situ dikatakan bahwa dalam polis disebutkan bangunan apa yang menempel atau yang berdekatan dengan barang-barang yang dijamin dan harus disebutkan cara-cara pemakaian bangunan itu, tujuannya agar dapat dipikirkan sampai di mana terdapat risiko terhadap barang-barang yang dijaminkan.pada pertanggungan mengenai hak milik yang berupa gedung, tertanggung dapat minta diperjanjikan bahwa 1) kerugian yang timbul pada gedung itu supaya diganti; 2 ) gedung itu supaya dibangun kembali; dan 3) gedung itu supaya diperbaiki.

\section{KESIMPULAN}

1. Pelaksanaan asuransi kebakaran pada PT. Asuransi Takaful Umum Cabang Padang di awali dengan pengisian data oleh calon tertanggung pada Surat Permohonan Penutupan Asuransi 
Kebakaran (SPPAK). Setelah dilakukan kata mufakat oleh kedua belah pihak PT. Asuransi Takaful Umum menerbitkan atau membuat polis atau Polis Standar kebakaran Indonesia (PSKI)

2. Pelaksanan pengajuan dan pembayaran klaim pada PT. Asuransi Takaful Umum Cabang Padang dimulai dengan pengisian formulir laporan klaim oleh tertanggung dan penyerahan polis beserta berita acara mengenai peristiwa kebakaran, berikut rincian tentang penyebab kerugian dan kerusakan.

3. Kendala yang dihadapi dalam pelaksanaan asuransi kebakaran pada PT. Asuransi Takaful Umum Cabang Padang biasanya berasal dari peserta asuransi kebakaran itu sendiri. Pihak tertanggung sering tidak membaca dan memahami isi dari perjanjian yang terdapat dalam PSKI.

\section{SARAN}

1. Dalam pelaksanaan asuransi kebakaran, sebelum perjanjian asuransi kebakaran ditandatangani dan pada saat tertanggung menerima polis agar membaca, memahami dan mengerti isi dari Polis Standar Kebakaran Indonesia yang diterbitkan oleh perusahan asuransi. Hal ini semata-mata untuk menghindari terjadinya salah pengertian dalam pelaksanaan asuransi kebakaran nantinya.

2. Dalam pelaksanaan pembayaran ganti kerugian (klaim), pihak asuransi agar melakukan penyuluhan secara intensif kepada tertanggung sejelas- jelasnya, sehingga apabila terjadi peristiwa kebakaran maka tertanggung dapat segera melengkapi data-data atau dokumen klaim yang diperlukan dalam mengajukan tuntutan ganti kerugian kepada tertanggung.

3. Mengingat sering terjadi peristiwa kebakaran akhir-akhir ini, maka untuk mengurangi beban resiko yang mungkin akan timbul sebaiknya masyarakat mengasuransikan harta bendanya sesuai dengan prosedur yang ditetapkan oleh perusahaan asuransi. Memang diakui masih sedikit masyarakat yang menggunakan jasa asuransi, maka dari itu pihak asuransi harus lebih mensosialisasikan produk asuransi yang ditawarkan sehingga masyarakat tertarik menjadi peserta asuransi.

\section{KEPUSTAKAAN ACUAN}

Ali, Hasymi. (1993). Pengantar Asuransi. Jakarta: PT. Bumi Aksara 
Darmawi, Herman. (2000). Manajemen Asuransi. Jakarta: PT. Bumi Aksara

Dewi, Gemala. (2006). Aspek-aspek Hukum dalam Perbankan dan Perasuransian Syariah di Indonesia. Jakarta: Kecana

Gunanto. (1984). Polis Asuransi Kebakaran Indonesia. Jakarta: Tira Pustaka

Moleong, Lexy, J. (2007). Metodologi Penelitian Kualitatif. Bandung: PT. Remaja Rosdakarya

Prakoso, Djoko dan Murtika, I Ketut (2004). Hukum Asuransi Indonesia. Jakarta: PT. Rineka Cipta.

Salim, Abbas. (2000). Asuransi dan Manajemen Risiko. Jakarta: PT. Raja Grafindo Persada.
Simanjutak, Emmy Pangaribuan (1990). Hukum Pertanggungan. Yogyakarta: Seksi Hukum Dagang Fakultas Hukum UGM.

Sugiyono. (2007). Memahami Penelitian Kualitatif. Bandung: CV. ALFABETA

Sula, Muhammad Syakir. (2004). Asuransi Syariah (Life and General) Konsep dan Sistem Operasional. Jakarta: Gema Insani

Wirdyaningsih. (2005). Bank dan Asuransi Islam di Indonesia. Jakarta: Kencana 